\title{
Gruesome Spectacles Revisited: News Coverage of Botched Lethal Injections Since 2010
}

\author{
Haojun Zhuang ${ }^{1}$ \& Austin D. Sarat ${ }^{2}$ \\ ${ }^{1}$ Shanghai, China \\ ${ }^{2}$ Amherst, Massachusetts, United States \\ Correspondence: Haojun Zhuang, Shanghai, China. E-mail: sophiezhuang2021@outlook.com \\ Received: April 1, $2021 \quad$ Accepted: May 6, $2021 \quad$ Online Published: May 9, 2021 \\ doi:10.5539/jpl.v14n3p115 URL: https://doi.org/10.5539/jpl.v14n3p115
}

\begin{abstract}
This research is a continuation of the work done by one of the authors (Austin Sarat) in Gruesome Spectacles: Botched Executions and America's Death Penalty. That book examined newspaper coverage of botched executions, from hangings, the electric chair, and the gas chamber firing to the early usage of lethal injection. It covered the period 1890 to 2010 and paid particular attention to changes in newspapers' reporting of botched executions. It argued that the treatment of botched executions as "mishaps" rather than injustices blunted botched executions" impact on the death penalty abolitionist movement. In this paper, we discuss newspaper coverage of botched lethal injections since 2010, looking closely at nine such executions identified by the Death Penalty Information Center website. Recent news reporting has mainly confirmed Sarat's findings. However, a new component of the coverage of botched executions - interviews with the victims' families - further dampens the impact of botched executions on support for the abolition of the death penalty.
\end{abstract}

Keywords: Botched Execution, Death Penalty, Lethal Injection, News Coverage, United States

\section{Introduction}

On September 15, 2009, the execution of Romell Broom, 59, who had been convicted in Ohio for the 1984 abduction, rape, and killing of 14-year-old Tryna Middleton, was stopped when the execution team failed, after repeated efforts to find a stable site to inject deadly drugs (Driehaus, 2009). Throughout this process, Broom winced and grimaced as needles were inserted in different parts of his body. At one point, he covered his face with both hands and appeared to be sobbing, his stomach heaving (Sarat, 2014).

Broom's execution began at roughly 2 p.m. and ended two hours later only after a call to the governor who granted Broom a reprieve (Barbash, 2016). As Fred Barbash of The Washington Post observed,

In the course of that time period, they jabbed, poked and stuck the man at least 18 times, twisting and turning catheters this way and that. They made holes in his arms, legs and elbows, his wrists, the backs of his hands and his ankles, inserting catheter needles repeatedly into 'already swollen and bruised sites.' His veins bulged. One of them 'blew.' They took breaks, leaving the man on the gurney, and then came back to try again. The medical team would 'withdraw the catheter partway and then reinsert it at a different angle.' (Barbash, 2016)

Following his botched execution, Broom filed suit, claiming that a second attempt to execute him would violate the Eighth and Fourteenth Amendments. The Ohio Supreme Court ruled against Broom. It held that an execution does not begin until lethal drugs enter the IV line. Hence, Broom's execution never began, and a second execution attempt would not violate his rights. (Romell v. Broom, 2016) Broom, who was again scheduled to be executed in 2020, had that execution date moved again because of the COVID 19 pandemic.

Broom's case and its news coverage were one of the many described in Gruesome Spectacles: Botched Executions and America's Death Penalty. Sarat examined newspaper reporting of botched executions from 1890 to 2010 . The newspapers' consistent focus on portraying botched executions as mishaps rather than injustices blunted their impact of botched executions on the abolitionist movement.

In this paper, we examine media coverage of botched lethal injections since 2010. Recent news reporting is similar to what Sarat found out about early twentieth century news reporting. However, a new component - interviews 
with the victims' families - further discourages public support for the abolition of the death penalty.

\section{Newspaper Coverage of Botched Executions from 1890 to 2010: Austin Sarat's Gruesome Spectacles}

In 1977, Oklahoma became the first state to adopt lethal injection as its method of execution, transitioning from the use of the electric chair. In 2008, the Supreme Court decided that the use of lethal injection as an execution method was constitutional and approved the then standard 3-drug combination of sodium thiopental, pancuronium bromide, and potassium chloride -- an anesthetic followed by a paralytic agent and lastly a deadly drug that stops the heart. At that time, 27 of 36 states that allowed capital punishment employed lethal injection as their sole method. At least 30 of those states used the identical 3-drug cocktail. (Baze et al. v. Rees, 2008)

Currently, all states that retain capital punishment use lethal injection as their primary execution method (National Conference of State Legislatures, 2020). However, due to drug shortages in recent years, states have adopted new drug protocols (Death Penalty Information Center [DPIC], 2020). In Glossip v. Gross (2015), the Supreme Court decided that the use of midazolam, a sedative, in an execution is constitutional and found that death row inmates can only challenge their states' drug combination if there is an available, less painful alternative. (Glossip v. Gross, 2015)

From 1900 to 2010, of all execution methods lethal injection was most frequently botched, with $7.12 \%$ of lethal injections being botched. (Sarat, 2014) Botched lethal injections most commonly result from either failure to adequately sedate the inmate, or failure to find a stable site for injection.

In Gruesome Spectacles, Sarat (2014) described three styles of news reporting of botched executions: dual narratives of sensationalism and recuperation in the early twentieth century, the decline of sensationalism and the rise of professionalism in the mid-twentieth century, and balanced reporting in the late twentieth century.

In the early twentieth century, news reporting minimized the pain experienced during botched execution and offered reassurance that botched executions were aberrations. The reporting downplayed the state's responsibility when executions went wrong. Botched executions were not portrayed as failures of the state or of the institution of capital punishment. Moreover, newspapers offered recuperative storylines that presented justifications and reasoned explanations for botched executions. (Sarat, 2014)

In the mid-twentieth century, news reports embraced an ethic of objectivity and largely remained silent about the brutality of botched executions. The rise of professionalism in news reporting contributed little to the abolition movement. Moreover, reports of botched executions sometimes shifted responsibility from the state to the condemned themselves. (Sarat, 2014)

In the late twentieth century, news reporting evinced a balanced style, consisting of interviews with both the prosecution and the defense. Here again stories of botched executions became contested narratives in which one side emphasized the horror of the botch while the other often insisted that nothing had gone wrong. (Sarat, 2014)

\section{News Coverage of Botched Lethal Injections after 2010}

While we followed the basic methodology used in Gruesome Spectacles, we recognized that there has been a decline in the readership of printed newspapers. Yet the rise of digital news has maintained the social importance of newspapers. Data for 2018 provided by the Alliance for Audited Media shows newspapers' rising digital circulation, with weekday circulation up 6 percent and Sunday up 8 percent. According to independently produced reports from The New York Times and The Wall Street Journal, both companies experienced substantial gains in digital circulation in the past year: 27 percent for the Times and 23 percent for the Journal, on top of large gains in 2017. The boost in digital readership has mitigated the well document drop in print circulation. (Barthel \& Pew Research Center, 2019)

We started by examining coverage of botched lethal injections in The New York Times and The Washington Post and in the most widely circulated newspapers in several states, including The Columbus Dispatch of Ohio, The Atlanta Journal-Constitution of Georgia, The Oklahoman, The Arizona Republic, and Alabama Local News. Finally, we also included coverage provided by CBS News, NBC News, ABC News, and MSNBC to complement the reporting of botched executions in newspapers. We examined coverage of each botched execution in the post2010 period, paying particular attention to both the content and style of that coverage.

Below we report on news coverage of post-2010 botched executions.

\subsection{Brandon Joseph Rhode}

On September 27, 2010, lethal drugs flowed through Georgia inmate Brandon Joseph Rhode's veins for 14 minutes before he was pronounced dead. Rhode had been convicted for the 1998 murders of Steven Moss, 37, his 11-yearold son Bryan and 15-year-old daughter Kristin during a burglary of their home in Jones County, Georgia. A week 
before his execution, the 31-year-old Rhode had slashed his arms and throat in a suicide attempt. (Martinez, 2010) His attempted suicide caused severe blood loss and left him with brain damage. (Friedman, 2010)

Nonetheless, Georgia went ahead with Rhode's execution. It didn't go as expected:

Medics tried for about 30 minutes to find a vein to inject the three-drug concoction. The prisoner's eyes darted around the room before the lethal mixture began coursing through his veins. Within minutes he was staring blankly at the ceiling of the death chamber. Moments before Rhode was pronounced dead he turned his head, exposing a bandage over the part of his neck he slashed. (Martinez, 2010)

Despite those difficulties, none of the news sources we examined characterized this lethal injection as botched, nor even as prolonged.

\subsection{Dennis B. McGuire}

On January 16, 2014, convicted killer Dennis B. McGuire experienced a great deal of pain and suffering during his execution. McGuire, 53, gasped, choked, clenched his fists and appeared to struggle against his restraints for about 10 minutes before being pronounced dead at the Southern Ohio Correctional Facility. After the drugs were administered, McGuire's death took 26 minutes, the longest timer of any Ohio execution since 1999.

The New York Times and The Columbus Dispatch called this execution "prolonged" and reported that McGuire experienced "repeated cycles of snorting, gurgling and arching his back, appearing to writhe in pain." (Johnson, 2014) Newspaper reporters interviewed McGuire's adult children and his lawyer who had watched McGuire suffer.

“'He started making all these horrible, horrible noises, and at that point, that's when I covered my eyes and my ears," said Ms. McGuire, who watched the execution on Thursday at the Southern Ohio Correctional Facility, near Lucasville. "“He was suffering." Allen Bohnert, the lawyer who represented Mr. McGuire, called the execution "'a failed, agonizing experiment by the State of Ohio."' (Goode, 2014)

The McGuire coverage shares many similarities with the coverage described in Gruesome Spectacles, but with an added element, namely interviews with the victims' families. (The Associated Press, 2014) The New York Times and The Columbus Dispatch both reported the views of McGuire's victims' families: "'He is being treated far more humanely than he treated her," and " There has been a lot of controversy regarding the drugs that are to be used in his execution, concern that he might feel terror, that he might suffer. As I recall the events preceding her death, forcing her from the car, attempting to rape her vaginally, sodomizing her, choking her, stabbing her, I know she suffered terror and pain. He is being treated far more humanely than he treated her." (Johnson, 2014)

\subsection{Clayton D. Lockett}

Oklahoma State Corrections Department officials halted the execution of Clayton Derrell Lockett's execution on April 29, 2014, after a botched lethal injection. A medical technician had trouble inserting the IV and after many failed efforts finally was able to place it. The first drug, a sedative intended to knock Lockett out for the rest of the procedure, was started. Ten minutes later, Lockett was declared to be unconscious, and the team started to administer the other two drugs, a paralytic and one that makes the heart stop. (Eckholm, 2014) At that point, witnesses reported that things began to go awry.

Mr. Lockett's body twitched, his foot shook and he mumbled. He tried to rise and exhaled loudly. Prison officials pulled a curtain in front of the witnesses and the doctor discovered a "vein failure," (Eckholm, 2014) At 7:06, about 40 minutes after the start of the execution, Lockett died of a heart attack. (Eckholm, 2014)

State officials contended that the difficulties with this execution did not result from the drugs themselves, but rather from the placement of the IV line. "'This was botched, and it was difficult to watch," said David Autry, one of Mr. Lockett's lawyers. Dean Sanderford, another lawyer for Mr. Lockett, said, “'It looked like torture." Without effective sedation, the second two drugs are known to cause suffocation and pain. (Eckholm, 2014)

Clayton Lockett's stepmom, Ladonna Hollins, told NBC News that

"'When they opened up the curtain, he was still alive. He was alive after they injected him! It did not do the job. They screwed it up. If they cannot effectively execute a person, then don't do it. What is wrong with this system?"' Hollins, who expressed sympathy for his victim's family, said her son had made his peace with the idea that he would be executed but feared a painful end. Deanna Parker, Lockett's aunt, said what happened in the death chamber "'was exactly what he feared."' (Eckholm, 2014)

Lockett had been sentenced to death for shooting 19-year-old Stephanie Nieman with a sawed-off shotgun and watching as two accomplices buried her alive in 1999. (Black, 2014) NBC News reported that before Lockett's execution, his victim's family issued a brief written statement in which they recalled that she loved children and 
had worked at Bible school. "'She was the joy of our life," they said. "We are thankful this day has finally arrived and justice will finally be served." (Black, 2014)

News coverage of Lockett's execution used the words "failure" and "botched" to describe it. However, it offered the typical balanced reporting that Sarat described in his research. Finally, Lockett's news coverage put his family's reaction and his victim's family's reaction side by side.

\subsection{Joseph R. Wood III}

On July 23, 2014, condemned Arizona prisoner Joseph Rudolph Wood repeatedly gasped for one hour and 40 minutes during his execution. (Eckholm, 2014) Newspapers called this execution "prolonged," "failed," "bungled," and "botched." According to Arizona Republic reporter Michael Kiefer, who witnessed the execution, Wood initially seemed to be unconscious, but soon started gasping for air. Kiefer said. "I counted about 640 times he gasped."” (Ortega, Kiefer \& Dale, 2014)

“The worst part about Joseph Wood's botched execution was, it was entirely predictable and avoidable," Diann Rust-Tierney, executive director of the National Coalition to Abolish the Death Penalty, said in a statement noting that the same combination of drugs had been used in a problematic execution in Ohio earlier in the year. (Ortega, Kiefer \& Dale, 2014)

On the other hand, state officials insisted that Wood had been comatose throughout the procedure and did not suffer. They suggested that the sound witnesses heard was Wood snoring. (Eckholm, 2014)

Wood was executed for the 1989 murders of his estranged girlfriend, Debra Dietz, and her father, Eugene Dietz. Some family members of the victims said they were not concerned about what happened during the execution. (Eckholm, 2014) “"This man conducted a horrific murder and you guys are going, 'Let's worry about the drugs,"” Richard Brown, brother-in-law of Debra Dietz, told The A.P. “'Why didn't they give him a bullet? Why didn't we give him Drano?"' (Eckholm, 2014)

Meanwhile, The Arizona Republic also highlighted the victims' family's response.

“"Everybody here said it was excruciating,"” said Jeanne Brown, Debra Dietz's sister. "“You don't know what excruciating is. Seeing your dad lying there in a pool of blood, seeing your sister lying there in a pool of blood, that's excruciating." Her husband, Richard Brown, who witnessed the murders, said, "'What I've seen today, you guys are blowing this all out of proportion about these drugs."” (Ortega, Kiefer \& Dale, 2014)

\subsection{Brian Keith Terrell}

Brian Keith Terrell, convicted of the 1992 killing of a 70-year-old man, was executed on December 9, 2015, at the Georgia Diagnostic and Classification Prison. (Jones, 2015) Aimee Jones, a reporter from The Newton Citizen newspaper was allowed to be in the witness room when Terrell was strapped to the gurney and IV lines were placed. (Associated Press, 2015) But, as in other lethal injections, the process of placing those lines did not go smoothly. It took an hour for the nurse assigned to the execution to get IVs inserted into both of Terrell's arms. He repeatedly winced and registered pain as those efforts unfolded.

Newspaper reports, including the one filed by Jones, made little mention of the problems with Terrell's execution.

Jones reported that,

Initially Terrell appeared stoic as he was escorted into the room, and sat up periodically to watch as medical personnel prepped him for the injection and to look out at witnesses gathered on the other side of the window. Once the first IV was injected in his right arm, however, Terrell began to show signs of emotion, breathing more heavily and shaking intermittently. Prison medical staff struggled to get the second IV in Terrell's left arm, eventually resorting to placing one in his hand. Occasionally his breathing increased and he continued to shake before calming down. About an hour later, Georgia Diagnostic and Classification State Prison Warden Bruce Chatman read the death warrant aloud as Terrell looked out at other witnesses who gathered, including Newton County Sheriff Ezell Brown. Terrell appeared to mouth, "'I didn't do it,"” and nod toward Brown. Brown acknowledged him by slightly nodding in return. Terrell laid back down as the sedative pentobarbital began to make it through the IVs, looking up again one more time before succumbing to the drug. (Jones, 2015)

Readers were left to imagine what the struggle referred to by Jones involved or whether it caused Terrell to suffer.

\subsection{Brandon Astor Jones}

On Wednesday, February 3, 2016, the state of Georgia executed its then oldest inmate, Brandon Astor Jones, 72 , 
who had been convicted in 1979 for the killing of a convenience store manager, Roger Tackett, during an armed robbery. (Helsel, 2016) As The Atlanta Journal-Constitution reported,

It took more than an hour to prepare Jones for his lethal injection. According to a media witness who monitored the setup, it appeared they had to insert an IV into his groin area, which is protocol if the nurses cannot find accessible veins in the inmate's arms. Jones fought death. His eyes closed within a minute of the warden leaving the execution chamber, but 6 minutes later his eyes popped open. He looked at a clock on the wall, and then appeared to look at the man who prosecuted him in 1979, former Cobb County District Attorney Tom Charron, who was sitting on the front row. (The Associated Press, 2016)

After Jones' execution, The Atlanta Journal-Constitution reported that Tackett's daughter, Katie Tackett King, and his widow, Christine Bixon, who remarried several years after Tackett's murder, did not witness the execution. Instead, King, who was 7 when her father was slain, waited at her Cherokee County home with Bixon. King and Bixon had said previously that while they did not celebrate Jones' death, it needed to happen for justice to be served. (Cook, 2016)

In this case, as in others we've reviewed, the media gave a prominent place to the views of family members of the murder victims. In so doing, it ensured that readers balanced the suffering associated with botched executions with the suffering of those whose lives are inexorably altered by the crimes of the condemned.

\subsection{Ronald Bert Smith, Jr.}

Ronald Bert Smith, Jr. was put to death for the 1994 murder of Huntsville convenient store clerk Casey Wilson. (Liptak, 2016) His lethal injection at the Holman Correctional Facility in Atmore, Alabama, took 34 minutes. During the execution, Smith heaved and coughed for 13 minutes. (Faulk, 2016) As The Alabama Local News reported,

During 13 minutes of the execution, from about 10:34 [p.m.] to 10:47 [p.m.], Smith appeared to be struggling for breath and heaved and coughed and clenched his left fist after apparently being administered the first drug in the three-drug combination. At times his left eye also appeared to be slightly open.... The Department of Corrections captain performed two consciousness checks before they proceeded with administering the next two drugs to stop his breathing and heart. The consciousness tests consist of the corrections officer calling out Smith's name, brushing his eyebrows back, and pinching him under his left arm. Smith continued to heave, gasp and cough after the first test was performed at 10:37 p.m. and again at 10:47 p.m. After the second one, Smith's right arm and hand moved. (Faulk, 2016)

Smith was pronounced dead at 11:05 p.m. (The Associated Press, 2016)

News sources did not characterize this lethal injection as being "botched," although they provided detailed accounts of Smith's struggle in the execution chamber. They reported that a family member of the victim was present at the execution, although the prison officials declined to identify that family member. (Faulk, 2016) No member of the victim's family made a statement. (The Associated Press, 2016)

\subsection{Alva Campbell}

Alva Campbell's failed lethal injection on November 15, 2017 was the third time in seven decades that a death row inmate in the United States survived an execution and the second time it happened in Ohio in recent years. (Stack, 2017)

A reporter for The Associated Press, who was at the Southern Ohio Correctional Facility in Lucasville as a news media witness to the execution, said the process was called off roughly 80 minutes after the execution began. The reporter wrote,

Members of the execution team, as it is known, spent about 30 minutes trying to find a usable vein in Mr. Campbell's arms and then tried to find a vein below his right knee. The executioners tried to comfort Mr. Campbell as they searched for a way to execute him, by patting him on the arm and shoulder. They also brought a wedge pillow for him to use on the gurney because he has breathing problems related to a longstanding smoking habit. Mr. Campbell shook hands with two guards about 80 minutes into the execution process when it appeared they had successfully found a vein. But two minutes later reporters were abruptly ushered out of the viewing area without being told why they had to leave. (Stack, 2017)

Meanwhile, The Columbus Dispatch described a similar scene:

For half an hour, the medical team used an ultraviolet light to probe his left and right arm for a vein. They stuck Campbell twice in his right arm, once in his left and once in his left leg before giving up. During the leg stick, Campbell threw his head back and appeared to cry out in pain.... When the execution was 
called off, Campbell removed his glasses and appeared to rub tears from his withered face and shook hands with several who had tried to facilitate his erstwhile executioner. (Schladen, 2017)

We note that in these descriptions, the newspapers did not categorize Campbell's execution as botched.

\subsection{Doyle Lee Hamm}

Doyle Lee Hamm, convicted of killing hotel clerk Patrick Cunningham in January 1987, survived his execution when his execution team could not find a stable IV site after three hours of trying. The State of Alabama ignored Hamm's lawyers warnings that his veins were in such bad shape that it wouldn't be possible for the state to carry out his execution humanely. (Specker, 2018)

NBC News reported as follows on Hamm's botched lethal injection:

An Alabama execution team left a death-row inmate with more than a dozen puncture marks in his legs and groin and may have penetrated his bladder and femoral artery before the lethal injection was called off, the prisoner's attorney said Sunday. (Conner, 2018)

Hamm's lawyer, Bernard Harcourt, was quoted saying,

"'This was clearly a botched execution that can only be accurately described as torture." During the execution, Hamm "'was lying there praying and hoping that they would succeed because of the pain, and collapsed when they took him off the gurney," Harcourt said. (Connor, 2018)

$N B C$ News featured a medical report commissioned by Harcourt that highlighted the fact that at one point during the execution "a large amount of blood began to accumulate in the region of Mr. Hamm's groin. The blood soaked a pad or drape, and another one was applied." (Connor, 2018) The medical report also described a frantic scene in the death chamber, which was closed to all but the execution team. It detailed the IV team "mashing" needles into Hamm's flesh in an effort to find a useable vein. (Connor, 2018)

The reporting left open the question of whether Hamm's botched lethal injection represented a culpable failure by the state or whether there was an innocent mishap in the procedure. The style of news reporting about Hamm's execution resembles the late twentieth century reporting described in Sarat's research.

\section{A New Twist to the Representation of Botched Executions in the News Media}

Gruesome Spectacles suggests that in the early twentieth century, newspapers downplayed or excused the state's failures in botched executions. By the mid-twentieth century, reporters presented narratives of botched executions as a balanced conversation among parties with different perspectives. (Sarat, 2014)

In the decade since 2010, the news media continued with balanced reporting, covering arguments from both prosecution and defense lawyers. However, they tended not to use the word botched to describe executions that encountered serious problems. Their reports did not highlight the suffering of the condemned and, when they did note it, tended to quote sources who insisted that the inmate did not suffer.

In addition to the balanced reporting that characterized coverage of botched executions in the early twenty-first century, interviews with the victim's family became more prevalent starting in 2010 . Out of the nine cases of botched executions between 2010 and 2020 in the Death Penalty Information Center compilation, news coverage of six of them quoted or mentioned the victims' families' statements about the execution. Reporters highlighted justice claims contained in those statements. Doing so added another layer to the meaning to botched executions. News reports compared the pain of executed convicts with the pain of victims' families.

This additional characteristic of news reporting downplays the injustice of botched lethal injections by putting it in a broader context. Doing so implicitly asks readers to choose sides, to ally themselves with the condemned or the families of murder victims. In the end, it may further minimize the potential of botched executions to play an important role in propelling the movement to end capital punishment in the United States.

\section{References}

Associated Press. (2010, September 28). Georgia executes killer who had attempted suicide on death row. The Florida Times-Union. Retrieved from https://www.jacksonville.com/article/20100928/NEWS/801244095

Associated Press. (2015, December 9). Georgia executes man for 1992 killing of his mother's friend. MSNBC. Retrieved from http://www.msnbc.com/msnbc/georgia-execution-brian-keith-terrell

Atlanta Local News. (2012, August 11). Clemency denied, Rhode scheduled for execution Tuesday. The Atlanta Journal-Constitution. Retrieved from https://www.ajc.com/news/local/clemency-denied-rhode-scheduledfor-execution-tuesday/rG5VIsFzA7nk4Klw8xE4VM/ 
Atlanta Local News. (2016, September 4). Georgia executes Brian Keith Terrell after struggling to find vein. The Atlanta Journal-Constitution. Retrieved from https://www.ajc.com/news/local/georgia-executes-brian-keithterrell-after-struggling-find-vein/ZhCwXEZb8IUwIw4O3iqloM/

Barbash, F. (2016, March 17). After 18 botched IV attempts on a screaming, bleeding inmate, Ohio gets another chance to execute him. The Washington Post. Retrieved from https://www.washingtonpost.com/news/morning-mix/wp/2016/03/17/after-18-botched-iv-attempts-on-ascreaming-bleeding-inmate-ohio-gets-another-chance-to-execute-him/

Baze et al. v. Rees, Commissioner, Kentucky Department of Corrections, et al., No. 07-5439 Stat. (Apr. 16, 2008).

Black, J., \& The Associated Press. (2014, April 30). Oklahoma inmate dies after execution is botched. NBC News. Retrieved from https://www.nbcnews.com/storyline/lethal-injection/oklahoma-inmate-dies-after-executionbotched-n93156

Brewer, G. L. (2014, April 29). Execution failure in Oklahoma: Clayton Lockett dies of heart attack after vein explodes. The Oklahoman. Retrieved from https://oklahoman.com/article/4744416/execution-failure-inoklahoma-clayton-lockett-dies-of-heart-attack-after-vein-explodes

CBS News. (2017, March 23). Ohio death row inmate Romell Broom, survivor of 2-hour botched execution, resists setting new date. CBS News. Retrieved from https://www.cbsnews.com/news/ohio-death-row-inmate-romellbroom-survivor-of-2-hour-botched-execution-resists-setting-new-date/

Connor, T. (2018, February 25). Lawyer describes aborted execution attempt for Doyle Lee Hamm as 'torture'. NBC News. Retrieved from https://www.nbcnews.com/storyline/lethal-injection/lawyer-calls-abortedexecution-attempt-doyle-lee-hamm-torture-n851006

Connor, T. (2018, March 5). Doyle Lee Hamm wished for death during botched execution, report says. NBC News. Retrieved from https://www.nbcnews.com/storyline/lethal-injection/doyle-lee-hamm-wished-death-duringbotched-execution-report-says-n853706

Cook, R., \& The Associated Press. (2016, September 4). For Georgia's oldest death row inmate, a startling last few minutes. The Atlanta Journal-Constitution. Retrieved from https://www.ajc.com/news/for-georgiaoldest-death-row-inmate-startling-last-few-minutes/nHWKtoF3oZpw4xATQU1H4N/

Death Penalty Information Center. (2020). Overview of lethal injection protocols. Death Penalty Information Center. Retrieved August 31, 2020, from https://deathpenaltyinfo.org/

Driehaus, B. (2009, September 16). Ohio plans to try again as execution goes wrong. The New York Times. Retrieved from https://www.nytimes.com/2009/09/17/us/17ohio.html

Eckholm, E. (2014, April 29). One execution botched, Oklahoma delays the next. The New York Times. Retrieved from https://www.nytimes.com/2014/04/30/us/oklahoma-executions.html

Eckholm, E. (2014, July 23). Arizona takes nearly 2 hours to execute inmate. The New York Times. Retrieved from https://www.nytimes.com/2014/07/24/us/arizona-takes-nearly-2-hours-to-execute-inmate.html

Examples of post-furman botched executions (M. L. Radelet, Comp.). (n.d.). Retrieved from https://deathpenaltyinfo.org/executions/botched-executions

Faulk, K. (2016, December 8). Alabama death row inmate Ronald Bert Smith heaved, coughed for 13 minutes during execution. Alabama Local News. Retrieved from https://www.al.com/news/birmingham/2016/12/alabama_death_row_inmate_is_se.html

Friedman, E. (2010, September 27). Brandon Rhode executed after suicide attempt left him brain damaged. $A B C$ News. Retrieved from https://abcnews.go.com/US/brandon-joseph-rhode-executed-denied-stay-arguingbrain/story?id=11736714

Glossip et al. v. Gross et al., No. 14-7955 Stat. (June 29, 2015).

Goode, E. (2014, January 17). After a prolonged execution in Ohio, questions over 'cruel and unusual'. The New York Times. Retrieved from https://www.nytimes.com/2014/01/18/us/prolonged-execution-prompts-debateover-death-penalty-methods.html

Helsel, P. (2016, February 3). Georgia executes its oldest death row inmate. NBC News. Retrieved from https://www.nbcnews.com/storyline/lethal-injection/georgia-set-execute-its-oldest-death-row-inmaten510011

Johnson, A. (2014, August 13). Dennis mcguire's execution was not 'humane,' doctor says. The Columbus 
Dispatch. Retrieved from https://www.dispatch.com/article/20140812/NEWS/308129896

Johnson, A. (2014, January 17). Inmate's death called 'horrific' under new, 2-drug execution. The Columbus Dispatch. Retrieved from https://www.dispatch.com/article/20140116/NEWS/301169709

Johnson, A. (2016, March 16). Inmate can face execution again after failed attempt, ohio supreme court rules. The Columbus Dispatch. Retrieved from https://www.dispatch.com/article/20160316/NEWS/303169774

Jones, A. (2015, December 9). Brian keith terrell executed by lethal injection. The Newton Citizen. Retrieved from https://www.rockdalenewtoncitizen.com/news/state/brian-keith-terrell-executed-by-lethalinjection/article_a8eb3db2-5e81-591c-b181-c3e0f7a7c0c7.html

Liptak, A. (2016, December 8). Alabama inmate executed after supreme court refuses a stay. The New York Times. Retrieved from https://www.nytimes.com/2016/12/08/us/politics/alabama-ronald-bert-smith-executionsupreme-court.html

Louisiana ex rel. Francis v. Resweber, Sheriff, et al., No. 142 La. Acts (Jan. 13, 1947).

Majors, S. (2009, September 16). Governor delays execution after suitable vein can't be found. Chillicothe Gazette. Retrieved from https://eji.org/files/dp-chillicothe-gazette-governor-delays-execution-09-16-09.pdf

Martinez, E. (2010, September 28). Brandon joseph rhode executed: Ga. kills inmate who attempted suicide. CBS News. Retrieved from https://www.cbsnews.com/news/brandon-joseph-rhode-executed-ga-kills-inmatewho-attempted-suicide/

National Conference of State Legislatures. (2020, March 24). States and capital punishment. National Conference of State Legislatures. Retrieved August 31, 2020, from https://www.ncsl.org

Newspapers fact sheet (M. Barthel \& Pew Research Center, Comps.). (n.d.). Retrieved from https://www.journalism.org/fact-sheet/newspapers/

Ortega, B., Kiefer, M., \& Dale, M. (2014, July 23). Execution of arizona murderer takes nearly 2 hours. The Arizona Republic. Retrieved from https://www.azcentral.com/story/news/local/arizona/2014/07/23/arizonaexecution-botched/13070677/

Queen, A. (2015, March 2). Execution of Brian Keith Terrell postponed indefinitely. The Newton Citizen. Retrieved from https://www.rockdalenewtoncitizen.com/news/execution-of-brian-keith-terrell-postponedindefinitely/article_7cc91e05-535a-5ab5-b27b-924676e6973e.html

Rankin, B. (2012, August 11). Rhode seeks stay of execution. The Atlanta Journal-Constitution. Retrieved from https://www.ajc.com/news/local/rhode-seeks-stay-execution/k6k4zioilSguvJreqUF1SJ/

Romell Broom v. State of Ohio, No. 16-5580 Stat.

Sarat, A. (2014). Gruesome spectacles: Botched executions and america's death penalty. Stanford Law Books, An Imprint of Stanford University Press. https://doi.org/10.1515/9780804791724

Schladen, M. (2017, November 15). After four unsuccessful needle pokes, columbus killer's execution called off. The Columbus Dispatch. Retrieved from https://www.dispatch.com/news/20171115/after-four-unsuccessfulneedle-pokes-columbus-killers-execution-called-off

Specker, L. (2018, February 22). Execution of Alabama inmate Doyle Lee Hamm called off. Alabama Local News. Retrieved from https://www.al.com/news/birmingham/2018/02/alabama_inmate_doyle_lee_hamm.html

Stack, L. (2017, November 15). Execution in Ohio is halted after no usable vein can be found. The New York Times. Retrieved from https://www.nytimes.com/2017/11/15/us/ohio-execution-alva-campbell.html

State v. Broom, 123 Ohio St.3d 114, 2009-Ohio-4778 Ohio Laws (Sept. 11, 2009).

State v. Broom, 146 Ohio St.3d 60, 2016-Ohio-1028 Ohio Laws (Mar. 16, 2016).

The Associated Press. (2014, January 25). Family sues in protracted Ohio execution. The New York Times. Retrieved from https://www.nytimes.com/2014/01/26/us/family-sues-in-protracted-ohio-execution.html

The Associated Press. (2015, December 9). Georgia man executed for murder of mother's friend. CBS News. Retrieved from https://www.cbsnews.com/news/georgia-man-brian-terrell-executed-for-murder-of-mothersfriend/

The Associated Press. (2016, December 9). Alabama executes killer Ronald Bert Smith Jr. after two temporary supreme court holds. CBS News. Retrieved from https://www.cbsnews.com/news/alabama-executes-killerronald-bert-smith-jr-after-two-temporary-supreme-court-holds/ 
The Associated Press. (2016, September 4). Georgia executes Brandon Astor Jones. The Atlanta JournalConstitution. Retrieved from https://www.ajc.com/news/local/georgia-executes-brandon-astorjones/jDioe9hdPGv2oj7mhVehnM/

The Associated Press. (2017, May 22). Court schedules 2nd execution attempt for Ohio killer. The Seattle Times. Retrieved from https://www.seattletimes.com/nation-world/court-schedules-2nd-execution-attempt-for-ohiokiller/

Zachariah, H. (2018, March 3). Ohio death row inmate Alva Campbell dies of natural causes. The Columbus Dispatch. Retrieved from https://www.dispatch.com/news/20180303/ohio-death-row-inmate-alva-campbelldies-of-natural-causes

\section{Copyrights}

Copyright for this article is retained by the author(s), with first publication rights granted to the journal.

This is an open-access article distributed under the terms and conditions of the Creative Commons Attribution license (http://creativecommons.org/licenses/by/4.0/). 